\title{
Transnational Adaptations: The Nineteenth-Century Novel Revisited through a Transcultural Lens
}

\begin{abstract}
This article aims to address issues of adaptation from the point of view of transcultural and transhistorical film adaptations of classic nineteenth-century realist novels. I propose to discuss a number of these adaptations, taking into account production aspects as well as stylistic elements that enhance the transnational/global angle of the films. There are many examples of these, including the popular Bride and Prejudice (2004), an adaptation of Jane Austen's novel by director Gurinder Chadha, or the film Trishna, directed by Michael Winterbottom (2012), which is based on Thomas Hardy's Tess of the D'Urbervilles. We can call them transcultural and transhistorical adaptations, since they relocate the narratives that inspired them to different geographical and historical settings. We will frame our discussion of these adaptations using theories of adaptation, namely those of Linda Hutcheon and Robert Stam, as well as within a discussion of transnational film studies.
\end{abstract}

Keywords: classic adaptations, film adaptation, transcultural adaptation, transnational adaptation

\section{On adaptation and the nineteenth-century realist novel: A brief overview}

An age pervaded by the "global screen," to use Lipovetsky and Serroy's phrase (2010), an age where reality is constantly mediated by some screen, can make the written page of the literary text as presented in the old medium of the book, or even in its updated version of the e-book, look almost obsolete. In this context, we can also see film and literature courses, which have in recent years become widespread in academic curricula in the humanities, as a sign of the difficult negotiation literature experts have to perform in order to meet the cultural expectations of generations of young (and not so young) adults whose cultural references are audio-visual as well as/rather than literary, and often popular rather than erudite. ${ }^{1}$

1 According to Marjorie Garber, literature and literary criticism, which were once a serious part of people's education, have been "replaced by expertise in science and in information technology, 
The bulky nineteenth-century novel, in particular, may well present its own difficulties to contemporary undergraduate students who have to read, among others, novels by Jane Austen, Charles Dickens, George Eliot, William Makepeace Thackeray, Thomas Hardy, or the Brontë sisters. In these circumstances, but not only in them, we might say that the screen adaptations of such novels might even help students read them.

Indeed, a good number of the many forms taken by the relation between film and literature is addressed by studies of film adaptation and comparative analyses of screen adaptations of literary works. This has led to the emergence of the scholarly trend of Adaptation Studies, which is now widespread and which, in turn, has rekindled theoretical discussions about processes of adaptation.

It is now commonly assumed, in these debates, that the least productive view to take when making a comparative analysis of a film and its source text is that of so-called fidelity analysis, that is, an analysis that seeks to "read" the film in terms of its closeness to the novel it is based on. The rejection of the fidelity assumption dates back to George Bluestone's pioneering book, Novels into Film (first published in 1957), in which even the idea of a comparative approach is fundamentally rejected on the basis of the specificity thesis. For Bluestone, that is to say, films and novels are such radically different media that the idea of trying to evaluate one in relation to the other is absurd. Thus, he states: "It is as fruitless to say that film A is better or worse than novel B as it is to pronounce Wright's Johnson's Wax Building better or worse than Tchaikovsky's Swan Lake. In the last analysis, each is autonomous, and each is characterized by unique and specific properties" (2003, 5-6).

The specificity thesis was more recently revived by Robert Stam (2005, 16-18), who, in his theorization of adaptation, starts from the idea of the "automatic difference" between the media, both on the grounds of the production processes involved and the very languages used (that is, aesthetic specificity). However, as Brian McFarlane states in an article entitled "It Wasn't Like That in the Book ...," for many people (especially in the field of literary studies), there still persists an idea that "the film is only valuable as it approximates the precursor text" $(2007,4)$. McFarlane contests this assumption by saying that, in most cases, such criticism views the film as a derivative copy of an original. He argues instead that "the film has the right to be judged as a film; then, one of the many things it also is [sic] an adaptation (it is also the product of a particular industrial system, a genre film, part of a tradition of national filmmaking, etc.)” (McFarlane 2007, 9).

on the one hand, and by visual literacy on the other"; "by visual," she further argues, "what is now meant is moving images (films, videos, television, MTV, advertising) as well as paintings and photographs" $(2012,13)$. 
Recent theories of adaptation, namely by Linda Hutcheon and the alreadyquoted Robert Stam, have preferred to emphasize the intertextual approach by focusing on, as Hutcheon argues, “adaptations as adaptations” (2006, 4). This means that, from the perspective of reception, "adaptation is a form of intertextuality: we experience adaptations (as adaptations) as palimpsests through our memory of other works that resonate through repetition with variation" (8) or, as Hutcheon states at another point, "repetition without replication" (7). The intertextual approach, described by both Hutcheon and Stam, redirects our interest in adaptations from the "fidelity" type of comparative analysis towards a framework where an adaptation, as a cultural product, is seen as a text in its own right. In the process, as is posited by Stam through his use of Gérard Genette's theorization of hyper- and hypo-textualities, this approach makes "manifest what is true of all works of art - that they are all in some level 'derivative"” (Stam 2005, 45). Hutcheon draws on the Darwinian theory of evolution to suggest a parallel with what happens when stories get adapted to different media and different contexts. Thus, she states:

Stories also evolve by adaptation and are not immutable over time. Sometimes, like biological adaptation, cultural adaptation involves migration to favourable conditions: stories travel to different cultures and different media. In short, stories adapt just as they are adapted. (Hutcheon 2006, 31)

\section{Transcultural and transhistorical adaptations}

This idea may be applied to our consideration of any particular film adaptation, but it is patently obvious in those cases where the adaptation openly asserts its transcultural and transhistorical process. Although, as Linda Hutcheon states, there is nothing new in "adapting from one culture to another," "what had been called 'cultural globalization' [...] has increased the attention paid to such transfers in recent years" (Hutcheon 2006, 145). This is the case with adaptations that appropriate more or less extensively a particular narrative, transposing it to a completely different historical and/or cultural context in a movement of re-location or "proximation" (Sanders 2010, 20). ${ }^{2}$ In these cases, as is explained by

2 In Palimpsests: Literature in the Second Degree (1997), Gérard Genette talks about a "movement of proximization," which he explains in the following terms: "As has just been indicated with reference to nationality, the habitual movement of diegetic transposition is a movement of proximization: the hypertext transposes the diegesis of its hypotext to bring it up to date and closer 
Julie Sanders, the adaptation contains "further layers of transposition, relocating [...] source texts not just generically, but in cultural, geographical and temporal terms" $(2010,20)$. Thus, in this case, the issue of fidelity to the original source is made even more irrelevant, because of the obvious differences between the two texts (novel and film) at all levels, from the narratological to the historical and the sociological. In other words, when stories are retold in completely different contexts, they allow for a process of transformation that emphasizes difference instead of similarity, and, as stated by Hutcheon, "local particularities become transplanted to new ground, and something new and hybrid results" $(2006,150)$.

This type of adaptation has been gaining currency lately, and we will find several examples of films that focus on a classic nineteenth-century realist novel and relocate it to a totally different time and geographical setting. Among the examples that readily come to mind is Bride and Prejudice (dir. Gurinder Chadha, 2004), which adapts Jane Austen's Pride and Prejudice (1813), transposing it to contemporary India (but also to Los Angeles and London) in the context of globalization. As will be apparent further on in this article, Bride and Prejudice is a particularly transnational film, aimed specifically at promoting ideas of multiculturalism and global diversity that are made visible in, among other things, the production (this is a UK/US/Indian co-production), the blending of different film languages (Bollywood, Hollywood, English costume film), and the transnational setting, with the American, Indian, and English characters (and cast) flying to and from Amritsar (Punjab, India), London, and Los Angeles, as well as Goa (India).

Of course, adaptations of Jane Austen occupy such a special place in adaptation studies that we are bound to find a few more transpositions of her novels to other historical and cultural contexts, as is the case with Clueless (dir. Amy Heckerling, 1995), an adaptation of Emma (1815), which takes place in the modern US. Another transposition of a realist novel to modern India is Trishna (dir. Michael Winterbottom, 2011), an adaptation of Thomas Hardy's Tess of the D'Urbervilles (1892). Winterbottom had already directed The Claim (2000), a transcultural adaptation of another Thomas Hardy novel, The Mayor of Casterbridge (1886), to another geographical dimension without changing the time frame - he sets the story in the California gold rush at the end of the nineteenth century. Dickens is another of the great realist writers whose novels have been extensively adapted to the screen; in his case, there are plenty of examples of relocated novels. Let us

to its audience (in temporal, geographic, or social terms).” He further argues that this movement "always consists in moving from the remote to the proximate" (Genette 1997, 304). Some commentators prefer Sanders's term "proximation" - for example, Understanding Film Theory by Ruth Doughty and Christine Etherington-Wright (2018, 34-35). 
take just two examples: the film Great Expectations (dir. Alfonso Cuarón, 1998), which transposes Dickens's novel (published in 1861) to present-day New York, and Boy Called Twist (dir. Tim Greene, 2004), a transposition of Oliver Twist (1838) to contemporary South Africa.

The aforementioned movement of "proximation," which is made by a re-contextualization of the source text to a contemporary time, performs an obvious updating of the text from the nineteenth century to the present, investing the film with an added interest, perhaps, for contemporary audiences. This is particularly important in commercial cinema, where productions have to be able to attract audiences in order to pay for the costs of production. Very often, the films take advantage of the melodramatic and/or sensationalist characteristics of the realist novels they adapt, highlighting certain timeless qualities found in these novels. This seems to be the case with a film like Winterbottom's Trishna, which appropriates the sensationalist themes of Tess of the D'Urbervilles, as far as the issues of sexual politics underlying the novel are concerned, and transposes them to present-day India in a movement that seems to be intended to focus on the situation of women in India today. As I have discussed elsewhere (Pereira 2016), Hardy's novels have been concerned with matters both of gender and of the representation of sexual desire; thus, this adaptation seems to perpetuate intense responses on the part of the viewer by drawing attention to a sensationalist depiction of the female character. This is achieved by a very vivid depiction of Jay's continuous abuse of Trishna/Tess in scenes that make visible the sexual violence exerted on the character and reinforce the constraining and constricting situation of women in Indian society today (Pereira 2016).

However, these films raise other important questions, given that we are dealing here with adaptations that are simultaneously transhistorical (that is, they appropriate source texts from the nineteenth century by transposing them to the twenty-first) and transcultural (in that they transfer sources from European/ English contexts to very different geographical and cultural contexts). The question that needs to be asked in relation to this kind of adaptation is: why keep using nineteenth-century novels to tell stories that are set in such different historical, geographical, and cultural contexts?

According to McFarlane and Hutcheon, some of the reasons for resorting to adapting literary classics have to do with recognizability and, consequently, the capacity to attract audiences; proven success; the prestige of borrowing from a well-established and respected art form, that is, exploring the "cultural capital" of a previous artwork (see McFarlane 2004, 6-7; Hutcheon 2006, 4-5, 85-92); but also, as Hutcheon $(2006,92-95)$ remarks, the desire to pay tribute to the adapted text by "copying" it, or the need to call the adapted text into question. This is the case, for example, when the film adaptation re-creates the hypotext by inter- 
rogating its politics and frames of reference by introducing scenes that are not present in the original text. Thus, for instance, an adaptation can introduce a feminist or postcolonial interpretation into its treatment of an existing novel or story, undermining or reinforcing strands of meaning that might or might not be latent in the source text. This would be the case with Bride and Prejudice, Gurinder Chadha's adaptation of Austen's Pride and Prejudice, which, in spite of following the romance pattern of the novel and Elizabeth Bennet's strong, independent character, draws attention to questions of cultural stereotyping of India, which is seen by the prejudiced North American William Darcy as a lesser culture.

On the other hand, these transcultural adaptations are very often also transnational productions, funded by different companies based in different countries or continents. A case in point would be Bride and Prejudice, an English and US co-production based on an English novel, but set in different world locations like Amritsar and Goa in India, Los Angeles, and London. The film displays an obvious global/transnational framework. Moreover, it is a blend of different national film traditions, a clear stylistic mix, fusing Bollywood musical with Hollywood romance and English heritage comedy, all three very popular and entertaining genres in their own contexts.

\section{Transcultural adaptations as transnational cinema}

As is mentioned by several authors who have dealt with questions of transnational cinema (Ezra and Rowden 2006b; Shohat and Stam 2003, 1-17; Desai 2004, 1-33; Higson 2006, 15-25), contemporary film production is a global business. In many senses, the idea of a global cinema can be applied to Hollywood cinema, taking into account its widespread global reach. This is not, however, the understanding of transnational cinema I propose here, since "transnational" may also refer to a counter-hegemonic film production, which is carried out, as Hamid Naficy points out, by exilic and diasporic "figures who work in the interstices of the social formations and cinematic practices” $(2006,111)$. As is stated by Elizabeth Ezra and Terry Rowden:

The transnational comprises both globalization - in cinematic terms, Hollywood's domination of world film markets - and the counterhegemonic responses of filmmakers from former colonial and Third World countries. The concept of transnationalism enables us to better understand the changing ways in which the contemporary world is being imagined by an increasing number of filmmakers across genres as a global system rather than as a collection of more or less autonomous nations. (Ezra and Rowden 2006a, 1) 
Writing more than ten years ago, Ezra and Rowden viewed this concept of transnational cinema as a consequence of a number of factors, which include "the increasing permeability of borders," generated both by "the acceleration of global flows of capital and a shifting geopolitical climate," including at that time "the end of the Cold War and the creation of the European Union," and the accelerated circulation of films enabled by new technologies, notably the video, the DVD, and digital media (2006a, 1).

The rapid circulation of films and the impact this has on contemporary film practices has reached another dimension in the age of the Internet, which has heightened the transnational dimension of cultural practices by deterritorializing them. As is argued by Arjun Appadurai in his influential Modernity at Large: Cultural Dimensions of Globalization, "electronic media decisively change the wider field of mass media and other traditional media," the other important mark of globalization being mass migration (1997, 3-4). According to Appadurai,

electronic mediation and mass migration mark the world of the present not as technically new forces but as ones that seem to impel (and sometimes compel) the work of the imagination. Together, they create specific irregularities because both viewers and images are in simultaneous circulation. (Appadurai 1997, 4)

Thus, in this sense, transnational cinema - or the cultural practice of a transnational cinema - transcends the idea of "national" cinemas and can be understood either as a set of production practices, or as a set of cultural practices of reading national cinemas in an era of globalized culture. As is argued by Will Higbee and Song Hwee Lim in the inaugural issue of the journal Transnational Cinemas, we can see

this shift towards the transnational as encouraged by a wider dissatisfaction expressed by scholars working across the humanities (in particular sociology, postcolonial studies and cultural studies) with the paradigm of the national as a means of understanding production, consumption and representation of cultural identity (both individual and collective) in an increasingly interconnected, multicultural and polycentric world. (Higbee and Lim 2010, 8)

Films like the ones mentioned above are good examples of this transnational trend in current film production, not only because they are indeed, at least in most cases, transnational productions, but also because they can be read in a context that defies national traditions. Paradoxically, they do so, in the case of our transnational adaptations, by using realist novels that are part of the canon of the national literatures to which they belong. 


\section{Transcultural, transhistorical, transnational}

What, then, is at stake when choosing to adapt a nineteenth-century realist novel to the contemporary, transcultural screen? How does the new context affect its original meaning? We can advance only a few tentative answers. In some of the cases, it seems that there is a clear emphasis on the question of cultural hybridity, which signals the intentional breaking of national boundaries in the films in question. Very often, their transnational outlook and their cultural hybridity are a reflection of the diasporic condition of economic globalization, with millions of immigrants living in transnational contexts. For example, when director Gurinder Chadha was asked in an interview whether her intention in directing Bride and Prejudice was to make an Austen adaptation or a Bollywood film, she enthusiastically stated that she wanted to do a Bollywood film, but added: "But I needed a good story that everyone was familiar with so they wouldn't be freaked out by the Indian film language being foreign! So I went with the Jane Austen novel that we all did at school and that we all know and just started to Indianise it" (quoted in Russell 2004). She therefore clearly targeted a mixed audience that might be acquainted with Bollywood films, but most probably would not be. The recognition of the need to make the film more culturally hybrid was obviously part of the decision-making process in a film that was funded by UK and US production companies (including the UK Film Council) and catered for a global audience.

Michael Winterbottom, the director of two of the transcultural adaptations that were referred to above, The Claim and Trishna, is another interesting example of a particularly transnational director. This much is argued in an article by Andrew Dix, who argues that Winterbottom's "is a cinema of persistent mobility and migration" $(2009,3)$. This is something that is clearly demonstrated in these two Hardy adaptations, ${ }^{3}$ which are simultaneously transnational co-productions and focus on the transnational mobility of the contemporary characters they depict.

Winterbottom seems to be attracted to the way Hardy's works denote a fissure between two worlds, the old rural world and the way it is caught in transition to a modern society. This may be the reason why he chooses to set Hardy's stories outside England. In relation to this, he states that the reason why he chose to place the story of Trishna/Tess of the D'Urbervilles in India has to do with this sense of mobility in a changing world that is not found in Britain. As he states in an

3 Winterbottom seems to be particularly attracted to the work of Thomas Hardy, since he has made three Hardy adaptations, the first of which, Jude (1996), adapted from the novel Jude the Obscure (1895), follows the novel's setting and time frame. 
interview: "Hardy's novels are often about modernity and speed and energy. But it's hard to get that sense of a dynamically changing world if you set one in this country. Here the problems are more to do with a lack of mobility rather than an excess of it" (quoted in Sandhu 2012). On the other hand, Tess of the D'Urbervilles had already been transposed to the screen several times before, ${ }^{4}$ and this may well account for Winterbottom's need to take a different approach to the narrative.

The same question of transience and mobility may be applied to his adaptation of The Claim, a film that brings to the fore a historical time that is contemporary to the historical time of Hardy's novel, but changes its location, reterritorializing it from Hardy's Wessex to the Sierra Nevada in California in 1867, just after the gold rush of the 1840s and the expansion of the American frontier. It tells the story of the pioneer men and women that first settled in this territory in the early days of the gold rush and the way the arrival of modernity, in the form of the railroad, will upset the balance of the town and the community that lived there, and ultimately destroy it, in order to create a new town and a new balance of power. The whole film draws attention to mobility and migration, since we are dealing with a mobile community that arrived here from different parts of the world. In the same way, in Trishna we are introduced to people that migrate and move from one place to another, be it from England to India (as in the case of Jay), or from a rural village in the north of India to the city of Jaipur and, from there, to Mumbai (in the case of Trishna). Both films display a sense of cultural hybridity linked to the places of mobility (social, migratory) where they are set that makes of them clear instances of transnationalism.

\section{Conclusion}

In all the cases that I have briefly discussed, we can see that the film in question was produced in order to cater for a transnational, mobile, and global audience. The fact that the source is a classic realist text - and a canonical one at that only reinforces strands of meaning that make it more contemporary and alive for a contemporary audience. In many ways, this form of adaptation thus works to reinforce the canonicity of the novels that filmmakers adapt and rewrite; it does so by drawing the attention of ever-new audiences to these texts, but also by making

4 This began with two silent movies made in the US, in 1913 (dir. J. Searle Dawley) and 1924 (dir. Marshall Neilan); the most notable example is a Franco-British film called Tess by Roman Polanski in 1979. 
use of a particularly well-known text which will probably make it easier to gather funding for the new film.

I would like to conclude with a note on questions of transnational filmmaking and transcultural adaptations of the nineteenth-century realist novel. The first is globalization, a recent trend in transnational film production. In a globalized world, films also feel the pressure of having to reach a fully globalized audience, one that is, to use Appadurai's term, ever more deterritorialized given the current processes of migration and global media. On the other hand, what these transcultural adaptations seem to bring to the fore is the contemporary significance of realist novels that are made to signify in different places, but with the, sometimes sadly, same themes. If this process draws attention to the global, somewhat timeless qualities and subjects of these novels, and thus to the universal qualities of human suffering, the films simultaneously use these universal themes to draw attention to localized problems and conditions. By doing so, they are, in a way, providing ever-renewed readings of old texts and in the process, making them more alive for contemporary audiences and readers alike.

\section{Works cited}

Appadurai, Arjun. Modernity at Large: Cultural Dimensions of Globalization. Minneapolis and London: University of Minnesota Press, 1997. Public World 1.

Bluestone, George. Novels into Film. 1957. Baltimore and London: The Johns Hopkins University Press, 2003.

Boy Called Twist. Dir. Tim Greene. Monkey Films, 2004.

Bride and Prejudice. Dir. Gurinder Chadha. Pathé Distribution, 2004.

The Claim. Dir. Michael Winterbottom. Pathé, 2000.

Clueless. Dir. Amy Heckerling. Paramount Pictures, 1995.

Desai, Jigna. Beyond Bollywood: The Cultural Politics of South Asian Diasporic Film. New York and London: Routledge, 2004.

Dix, Andrew. “'Do you want this world left on'? Global Imaginaries in the Films of Michael Winterbottom." Style 43.1 (2009): 3-25.

Doughty, Ruth, and Christine Etherington-Wright. Understanding Film Theory. 2nd ed. London: Palgrave, 2018.

Ezra, Elizabeth, and Terry Rowden. "General Introduction: What is Transnational Cinema?" Transnational Cinema: The Film Reader. Ed. Ezra and Rowden. London and New York: Routledge, 2006a. 1-12.

Ezra, Elizabeth, and Terry Rowden, eds. Transnational Cinema: The Film Reader. London and New York: Routledge, 2006b.

Garber, Marjorie. The Use and Abuse of Literature. New York: Anchor Books, 2012.

Genette, Gérard. Palimpsests: Literature in the Second Degree. Trans. Channa Newman and Claude Doubinsky. Lincoln and London: University of Nebraska Press, 1997.

Great Expectations. Dir. Alfonso Cuarón. 20th Century Fox, 1998. 
Higbee, Will, and Song Hwee Lim. "Concepts of Transnational Cinema: Towards a Critical Transnationalism in Film Studies.” Transnational Cinemas 1.1 (2010): 7-21. DOI: 10.1386/ trac.1.1.7/1 (6 September 2018).

Higson, Andrew. "The Limiting Imagination of National Cinema." Transnational Cinema: The Film Reader. Ed. Elizabeth Ezra and Terry Rowden. London and New York: Routledge, 2006. 15-26.

Hutcheon, Linda. A Theory of Adaptation. New York and London: Routledge, 2006.

Lipovetsky, Gilles, and Jean Serroy. L'Écran global: Culture-médias et cinéma à l'âge hypermoderne. Paris: Éd. Le Seuil, 2007.

McFarlane, Brian. Novel to Film: An Introduction to the Theory of Adaptation. Oxford: Clarendon Press, 2004.

McFarlane, Brian. "It Wasn't Like That in the Book ..." The Literature/Film Reader: Issues of Adaptation. Ed. James M. Welsh and Peter Lev. Lanham. Toronto, and Plymouth: The Scarecrow Press, 2007. 3-14.

Naficy, Hamid. "Situating Accented Cinema." Transnational Cinema: The Film Reader. Ed. Elizabeth Ezra and Terry Rowden. London and New York: Routledge, 2006. 111-130.

Pereira, Margarida Esteves. "Fallen Women on the Contemporary Global Screen: Transnational and Trans-Historical Adaptations of Eça de Queirós's The Crime of Father Amaro and Thomas Hardy's Tess of the D'Urbervilles." Transcultural Identity Constructions in a Changing World. Ed. Irene Gilsenan Nordin, Chatarina Edfeldt, Lung-Lung Hu, Herbert Jonsson, and André Leblanc. Frankfurt am Main: Lang, 2016. 275-290.

Russell, Jamie. “Gurinder Chadha interviewed by Jamie Russell.” BBCHome. 2004. http://www. bbc.co.uk/films/2004/09/16/gurinder_chadha_bride_and_prejudice_interview.shtml (7 May 2018).

Sanders, Julie. Adaptation and Appropriation. London: Routledge, 2010.

Sandhu, S. “India: Best Exotic Movie Hell?” The Guardian 16 February 2012. https://www. theguardian.com/film/2012/feb/16/india-best-exotic-movie-hell (7 May 2018).

Shohat, Ella, and Robert Stam. "Introduction." Multiculturalism, Postcoloniality, and Transnational Cinema. Ed. Shohat and Stam. New Brunswick and London: Rutgers University Press, 2003. 1-17.

Stam, Robert. "Introduction: Theory and Practice of Adaptation." Literature and Film: A Guide to the Theory and Practice of Film Adaptation. Ed. Stam and Alessandra Raengo. Malden, Oxford, and Victoria: Blackwell, 2005. 1-52.

Trishna. Dir. Michael Winterbottom. Artificial Eye, 2011.

Margarida Esteves Pereira is an associate professor at the Institute of Arts and Humanities, University of Minho. Her research has focused on the areas of English literature (modernist and contemporary literature), women's studies and gender, and the relationship between literature and film. Her publications include four co-edited volumes of essays, and she has authored two books. 
